\title{
Beban Kerja dan Stres Kerja Perawat
}

\author{
Putri Fitrah Alam ${ }^{1}$, Waode Suarni² ${ }^{2}$ Ida Sriwaty Sunarjo ${ }^{3}$ \\ Jurusan Psikologi \\ Fakultas Keguruan dan Ilmu Pendidikan, Universitas Halu Oleo \\ putrifitrahalam@gmail.com ${ }^{1}$, waodesuarni@yahoo.com ${ }^{2}$, ida_sunarjo@ymail.com ${ }^{3}$
}

\begin{abstract}
Abstrak : Stres merupakan masalah umum yang terjadi dalam kehidupan umat manusia dikarenakan stres sudah menjadi bagian hidup yang tidak bisa terelakkan. Seseorang yang rentan mengalami stres salah satunya adalah perawat terutama perawat yang bekerja di Rumah Sakit Jiwa karena pasien yang ditangani bukan pasien yang sakit secara fisik melainkan secara psikis. Penelitian ini bertujuan untuk mengetahui hubungan antara beban kerja dengan stres kerja pada perawat Rumah Sakit Jiwa Provinsi Sulawesi Tenggara. Jenis penelitian kuantitatif dengan desain korelasional. Populasi penelitian berjumlah 78 perawat. Subjek penelitian dipilih menggunakan teknik purposive sampling dengan kriteria perawat Rumah Sakit Jiwa Provinsi Sulawesi Tenggara yang berusia 26 sampai 35 tahun dengan masa kerja 1 sampai 4 tahun sehingga diperoleh 40 subjek. Instrumen penelitian menggunakan skala beban kerja dan skala stres kerja. Teknik analisis data menggunakan formula korelasi Product Moment Pearson dengan menggunakan SPSS (Statistical Package for the Social Sciences) versi 23.0. Hasil uji statistik menunjukkan beban kerja dengan kategori sedang sebanyak 75\% sedangkan stres kerja kategori sedang sebanyak 67,5\%. Koefisien korelasi yang diperoleh sebesar 0,450 dengan nilai signifikansi 0,004. Nilai korelasi yang diperoleh bertanda positif menunjukkan ada hubungan positif antara beban kerja dengan stres kerja pada perawat Rumah Sakit Jiwa Provinsi Sulawesi Tenggara sehingga hipotesis penelitian diterima.
\end{abstract}

Kata kunci : beban kerja ; rumah sakit jiwa ; stres kerja

\begin{abstract}
Stress is a common problem that occurs in human life, because stress has become an inevitable part of life. One person who is prone to experiencing stress is a nurse, especially a nurse who works in a Mental Hospital, because the patient is not only serving physically but psychologically. This study aims to see the relationship between workload and work stress on nurses at the Mental Hospital in Southeast Sulawesi Province. This type of quantitative research with a correlational design. The study population was probably 78 nurses. The research subjects were selected using a purposive sampling technique with criteria as criteria for nurses at the Mental Hospital of Southeast Sulawesi Province aged 26 to 35 years with 1 to 4 years working period in order to obtain 40 subjects. The research instrument used a workload scale and a work stress scale. The data analysis technique used a formula using Pearson's Product Moment using SPSS (Statistical Package for Social Sciences) version 23.0. The results of statistical tests showed that the workload in the medium category was $75 \%$ while the work stress in the moderate category was $67.5 \%$. The coefficient obtained is 0.450 with a significance value of 0.004. The value obtained which is obtained is positive indicating that there is a positive relationship between workload and work stress in the Southeast Sulawesi Province Mental Hospital nurses so that they are accepted.
\end{abstract}

Keywords : psychiatric hospital; workload; work stress 


\section{Pendahuluan}

Stres merupakan masalah umum yang terjadi dalam kehidupan umat manusia. Hal ini dikarenakan stres sudah menjadi bagian hidup yang tidak bisa terelakkan. Baik pada lingkungan kerja, keluarga, atau dimanapun, stres bisa dialami oleh seseorang. Dengan kata lain, stres pasti terjadi pada siapapun termasuk perawat dan akan menjadi masalah apabila stres tersebut tidak dapat diatasi. Hal ini didukung oleh pendapat Muatsiroh dan Siswati (2017) bahwa salah satu pekerjaan yang rentan mengalami resiko stres adalah perawat. Dalam melaksanakan pengabdiannya, seorang perawat tidak hanya berhubungan dengan pasiennya tetapi juga dengan keluarga pasien, teman pasien, rekan kerja sesama perawat, berhubungan dengan dokter, peraturan yang ada di tempat kerja serta beban kerja yang kadangkala dinilai tidak sesuai dengan kondisi fisik, psikis dan emosionalnya (Almasitoh, 2011). Seseorang yang rentan mengalami stres salah satunya adalah perawat terutama perawat yang bekerja di Rumah Sakit Jiwa karena pasien yang mereka tangani bukan pasien yang sakit secara fisik melainkan secara psikis. Hal ini membuat perawat kesulitan melakukan komunikasi dengan pasien yang berkaitan dengan tindakan keperawatan yang dilakukan (Eliyana, 2016). Berdasarkan informasi yang diperoleh dari perawat pada bulan September 2019, diketahui bahwa mereka juga membutuhkan adaptasi selama menangani pasien karena tidak sedikit perawat yang merasa takut dan waspada saat menangani pasien jiwa.

Rumah Sakit Jiwa merupakan rumah sakit khusus yang merawat pasien gangguan mental serta menyelenggarakan kegiatan pelayanan, pendidikan dan penelitian (Budi, 2011). Terdapat satu Rumah Sakit Jiwa di Sulawesi Tenggara yaitu Rumah Sakit Jiwa yang terletak di Kelurahan Tobuuha, Kecamatan Puuwatu, Kota Kendari.
Berdasarkan data yang diperoleh dari admin bagian kepegawaian pada bulan September 2019, Rumah Sakit Jiwa provinsi Sulawesi Tenggara memiliki 10 ruang perawatan yang terdiri dari ruang flamboyan, ruang melati, ruang matahari, ruang akut, ruang srikandi, ruang asoka, ruang UGD (Unit Gawat Darurat), ruang anggrek, ruang mawar dan ruang delima. Data mengenai jumlah perawat pada bulan September 2019 yang diperoleh dari ruang kepegawaian Rumah Sakit Jiwa adalah 78 orang.

Perawat Rumah Sakit Jiwa sebagai tenaga kesehatan memiliki tuntutan kerja yang tinggi. Tekanan-tekanan dalam merawat orang lain, menyaksikan situasi yang menyakitkan, dan intensitas interaksi yang tinggi terhadap pasien, keluarga pasien maupun staf kesehatan lain membuat perawat harus pandai dalam mengatur diri, baik dari segi sikap maupun emosi. Seringkali perawat menghadapi situasi yang tidak menyenangkan di tempat kerjanya disebabkan karena perilaku pasien yang mampu membuat perawat kehilangan konsentrasi. Selain itu, perawat juga harus menghadapi komplain dari keluarga pasien yang kurang puas terhadap pelayanan yang dilakukan. Perawat dituntut bekerja secara profesional serta mampu melakukan komunikasi secara baik. Hal-hal tersebut terus terulang setiap hari sehingga membuat perawat dihadapkan pada situasi yang penuh dengan tuntutan (Setiyana, 2013). Perawat dengan tuntutan kerja yang tinggi menyebabkan aktivitas kerja yang meningkat sehingga waktu istirahat akan berkurang. Hal tersebut dikarenakan banyaknya jumlah pasien yang akan menerima pelayanan dari perawat (Kirana \& Dwiyanti, 2017). Tuntutan dari pihak organisasi dan interaksi dengan pekerjaan serta beban kerja yang berat akan mendatangkan konflik bagi perawat.

Berdasarkan informasi yang diperoleh dari beberapa perawat Rumah Sakit Jiwa pada bulan Oktober 2019 diketahui bahwa Perawat Rumah Sakit 
Jiwa sering memiliki beberapa masalah saat menjalankan pekerjaannya, seperti menghadapi beberapa pasien yang mengamuk ataupun gelisah dan pasien yang menolak memberikan respon kepada perawat ketika diajak berkomunikasi sehingga membuat perawat stres. Ketika hal ini terus terjadi, kondisi psikologis perawat akan menurun, ia menjadi tertekan dan merasa tidak nyaman dengan pekerjaannya sehingga keadaan ini dapat mengakibatkan stres kerja. Ketika indikasi stres sudah muncul pada perawat, mereka akan cenderung memiliki kinerja yang buruk dalam hal kualitas perawatan pasien, seperti menjadi kurang konsentrasi, mudah lelah dan terkadang muncul perilaku yang kurang profesional sehingga pelayanan terhadap pasien menjadi kurang optimal (Isnainy, Furqoni, Aryanti \& Asdi, 2019).

Stres di tempat kerja sering disebabkan karena adanya ketidaksesuaian antara kemampuan seseorang dengan tuntutan tugas yang diterima. Hal ini sesuai dengan pendapat Maharani \& Budianto (2019) bahwa stres kerja perawat terjadi apabila dalam bertugas mendapatkan beban kerja yang melebihi kemampuannya sehingga perawat tersebut tidak mampu memenuhi atau menyelesaikan tugasnya. Haryanti, Aini \& Purwaningsih (2013) berpendapat bahwa kondisi dan beban kerja masing-masing ruangan perlu diketahui agar dapat ditentukan kebutuhan kuantitas dan kualitas tenaga perawat yang diperlukan agar tidak terjadi beban kerja yang tidak sesuai yang dapat menyebabkan stres kerja. Stres kerja adalah suatu kondisi yang memicu ketegangan dan menimbulkan ketidakseimbangan fisik dan psikis yang dapat berpengaruh terhadap emosi, proses berpikir, dan kondisi seseorang (Fahmi, 2016). Apabila perawat tidak siap dengan kondisi tersebut dapat menimbulkan ketegangan pada perawat yang berakibat timbulnya stres yang dapat mempengaruhi kondisi dari perawat itu sendiri.
Orang-orang yang mengalami stres akan merasakan kekhawatiran yang berlebihan sehingga mereka sering menjadi mudah marah, agresif, tidak dapat rileks atau memperlihatkan sikap yang tidak kooperatif yang akan berdampak pada kinerja seseorang. Hal ini didukung oleh pendapat Robbins \& Judge (2016) mendefinisikan stres kerja sebagai beban kerja yang berlebihan, perasaan susah dan ketegangan emosional yang menghambat performance individu.

Perilaku pasien gangguan jiwa yang sulit diprediksikan dan berbahaya juga menuntut perawat untuk lebih berhatihati dan waspada dalam memberikan perawatan. Berbagai cara yang dilakukan oleh perawat untuk mengatasi agresivitas pasien yang diarahkan padanya akan menimbulkan berbagai dampak negatif baik pada diri perawat sendiri maupun pasien. Jumlah pasien yang selalu berubah dan kondisi pasien yang bervariasi membuat perawat sangat mudah mengalami kelelahan (Pongantung, Kapantouw \& Kawatu, 2018). Situasi yang tidak kondusif seperti perilaku agresif harus segera diatasi agar tidak berakibat buruk bagi pasien dan perawat (Permatasari \& Utami, 2018). Apabila situasi yang menekan ini tidak segera diatasi, tidak menutup kemungkinan akan memunculkan stres pada diri perawat. Stres kerja merupakan ancaman bagi orang-orang yang bekerja di bidang industri kesehatan karena mereka bertanggung jawab untuk menyediakan perawatan kesehatan (Puteri \& Syaebani, 2018).

Penelitian yang dilakukan oleh Lasima (Kalendesang, Hendro \& Reginus, 2017) menemukan bahwa beban kerja yang berlebihan yang tidak segera diatasi maka akan menjadi sumber yang potensial munculnya stres kerja pada perawat. Segala macam bentuk stres pada dasarnya disebabkan oleh kurang mengertinya manusia akan keterbatasan dirinya sendiri (Anoraga, 2014). Lebih lanjut dijelaskan bahwa seseorang yang kurang mampu 
mengerjakan tugas-tugas yang diberikan dapat menyebabkan stres kerja. Hal ini didukung oleh penelitian Purbaningrat (2015) bahwa ada hubungan yang signifikan antara beban kerja dengan stres kerja artinya jika beban kerja rendah maka stres kerja juga memiliki nilai yang rendah dan sebaliknya apabila beban kerja tinggi maka akan mengakibatkan stres kerja yang tinggi pula.

Data yang diperoleh dari admin ruang kepegawaian pada bulan Oktober 2019 diketahui perawat Rumah Sakit Jiwa Provinsi Sulawesi Tenggara memiliki uraian tugas-tugas yang terdiri dari; melakukan pengkajian keperawatan dasar, melakukan massage pada kulit tertekan serta memfasilitasi keluarga untuk mengekspresikan perasaan. Selain itu, perawat melakukan komunikasi terapeutik dalam pemberian asuhan keperawatan, melakukan restrain/fiksasi pada pasien dalam rangka melakukan upaya preventif, melakukan dokumentasi proses keperawatan pada tahap pengkajian keperawatan. Adapun tugas lainnya adalah melakukan dokumentasi pelaksanaan tindakan keperawatan, memfasilitasi suasana lingkungan yang tenang dan aman, memfasilitasi kebutuhan spiritual klien dan memberikan dukungan dalam kehilangan ataupun berduka serta kematian.

Berdasarkan data jumlah pasien yang diperoleh dari admin ruang Rekam Medik Rumah Sakit Jiwa pada bulan Oktober 2019, jumlah rata-rata pasien rawat jalan dari bulan Januari sampai Oktober 2019 adalah 839 pasien sedangkan jumlah rata-rata pasien rawat inap dari bulan Januari sampai Oktober 2019 adalah 276 pasien. Dapat disimpulkan ada rasio antara jumlah perawat dan jumlah pasien. Biasanya 1 perawat Rumah Sakit Jiwa melakukan 1 sampai 2 tugas kepada 10 sampai 14 pasien karena kurangnya jumlah perawat yang tersedia dalam setiap shift. Tugastugas perawat harus diselesaikan dalam satu hari kerja. Menurut Febriani (2017) bahwa rasio antara jumlah perawat dan pasien dengan standar 1:10 tidak seimbang karena akan menyebabkan perawat memiliki beban kerja yang lebih banyak sehingga memicu stres kerja.

Wawancara dilakukan di Rumah Sakit Jiwa Provinsi Sulawesi Tenggara pada tanggal 3 Oktober 2019, tepatnya dilakukan terhadap 3 perawat di ruang Flamboyan. Berdasarkan hasil wawancara tersebut diketahui bahwa salah satu perawat ruang Flamboyan mengeluhkan asuhan keperawatan yang dilakukan cukup berat sebab pasien yang ditangani bukan pasien yang mengalami gangguan kesehatan secara fisik melainkan secara psikis. Perawat tersebut mengaku stres karena menangani pasien yang agresif sebab terkadang mendapat perlakuan yang tidak menyenangkan seperti disiram dengan air, diludahi bahkan dipukul oleh pasien. Bentuk stres perawat dapat dilihat dari seringnya perawat berbicara kepada pasien dengan intonasi suara yang tinggi, sedangkan 2 perawat lainnya mengaku mendapat perlakuan agresif dari pasien, tetapi hal itu dijadikan sebagai tantangan dalam diri sehingga dapat terhindar dari stres. Selain itu, perawat di ruang flamboyan berjumlah 11 orang dengan pasien sebanyak 32 orang. Shift kerja yang diterapkan ialah tiga rotasi yaitu shift pagi pukul 08.00-14.00 WITA dengan jumlah perawat 4-5 orang karena pasien rawat inap lebih banyak masuk saat pagi hari. Shift sore dimulai pukul 14.00-21.00 WITA dengan jumlah perawat 2-3 orang dan shift malam mulai pukul 21.00-08.00 WITA dengan jumlah perawat adalah 2-3 orang.

Begitu pula hasil wawancara yang dilakukan pada tanggal 5 Oktober 2019 kepada 3 perawat ruang UGD (Unit Gawat Darurat). Dari 3 perawat yang di wawancara, 2 orang perawat mengaku biasa saja saat merawat pasien agresif. Ketika perilaku agresif muncul, perawat mengikat pasien dan memberikan suntikan obat. Perawat mengaku stres apabila ada pasien yang sudah dipulangkan tetapi bersamaan dengan datangnya pasien 
agresif yang baru sementara jumlah perawat yang berjaga di ruangan biasanya hanya 1 orang. Sedangkan 1 perawat lainnya mengaku masih takut menghadapi pasien sehingga masih membutuhkan bantuan perawat lain saat menghadapi agresivitas pasien. Maka dari itu dengan memperhatikan permasalahan dan data yang diperoleh, peneliti berasumsi bahwa ada hubungan antara beban kerja dengan stres kerja pada perawat Rumah Sakit Jiwa Provinsi Sulawesi Tenggara.

\section{Metode Penelitian}

Penelitian ini menggunakan metode kuantitatif dengan desain korelasional. Terdapat dua variabel dalam penelitian ini yaitu variabel beban kerja sebagai variabel bebas dan variabel stres kerja sebagai variabel terikat. Populasi penelitian berjumlah 78 perawat. Sampel penelitian dipilih menggunakan teknik purposive sampling sehingga diperoleh 40 subjek. Kriteria subjek penelitian adalah perawat Rumah Sakit Jiwa Provinsi Sulawesi Tenggara yang berusia 26 sampai 35 tahun dengan masa kerja 1 sampai 4 tahun.

Instrumen pengumpulan data yang digunakan adalah skala beban kerja sebanyak 35 aitem dan skala stres kerja dengan jumlah aitem sebanyak 45 aitem. Validitas skala penelitian ini menggunakan koefisien validitas isi Aiken's V yang dirumuskan untuk menghitung contentvalid coefficient yang didasari oleh penilaian para ahli. Hasil uji coba skala beban kerja menunjukkan bahwa dari 59 item yang telah dianalisis, 35 item dinyatakan valid sedangkan 24 item lainnya dikatakan gugur karena tidak memenuhi standar koefisien korelasi yang telah ditetapkan yakni $\geq 0,25$. Sedangkan hasil uji coba skala stres kerja menunjukkan bahwa dari 59 item yang telah dianalisis, 45 item dinyatakan valid sedangkan 14 item lainnya dinyatakan gugur. Penelitian ini menggunakan SPSS (Statistical Package for the Social Sciences) versi 23.0 untuk mengetahui nilai reliabilitas dengan melihat skor Cronbach's alpha. Adapun nilai reliabilitas skala beban kerja adalah 0,816 sedangkan nilai reliabilitas skala stres kerja adalah 0,885 .

Definisi operasional mengenai variabel penelitian ini yaitu beban kerja menurut Hart dan Staveland (Dhania, 2010) merupakan perbedaan antara kemampuan dengan tuntutan tugas yang dilakukan oleh perawat Rumah Sakit Jiwa Provinsi Sulawesi Tenggara dan harus diselesaikan dalam waktu tertentu yang terdiri dari tingginya tuntutan dalam mengawasi pasien (mental demand), menulis laporan atau dokumentasi dari setiap tindakan keperawatan yang dilakukan kepada pasien (physical demand), tugas harus diselesaikan sebelum pergantian shift (temporal demand), harus mampu membuat pasien yang agresif merasa tenang (performance), bekerja lembur untuk menyelesaikan tugas (effort), dan perasaan tidak aman ketika berada di ruangan pasien (frustation level). Sedangkan stres kerja menurut Robbins \& Judge (2016) adalah beban kerja yang berlebihan dan perasaan tertekan yang dialami perawat Rumah Sakit Jiwa Provinsi Sulawesi Tenggara dalam menghadapi pekerjaannya yang terjadi karena adanya kesenjangan antara kemampuan dengan tuntutan dari pekerjaannya yang dapat dilihat dari fisiologis (otot terasa kaku dan kelelahan), psikologis (cemas dan mudah marah), dan perilaku (belum berada di rumah sakit saat waktu menunjukkan shift kerja serta tidur tidak teratur).

Penelitian ini menggunakan analisis deskriptif untuk memberikan deskripsi mengenai data dari variabel yang diukur. Untuk mengetahui apakah data terdistribusi secara normal yakni menggunakan teknik Kolmogorov Smirnov, uji linearitas menggunakan test from linearity, serta pengujian hipotesis menggunakan teknik Korelasi Product Moment Pearson dengan menggunakan SPSS (Statistical Package for the Social 
Sciences) versi 23.0.

\section{Hasil Penelitian dan Pembahasan}

Pada tabel di bawah ini, dapat diketahui bahwa sampel penelitian berjumlah 40 perawat Rumah Sakit Jiwa Provinsi Sulawesi Tenggara. Pada variabel beban kerja diketahui nilai minimum yang diperoleh sama dengan 80 , nilai maksimum sama dengan 117 dengan mean yang diperoleh sama dengan 92,32 sehingga diperoleh nilai standar deviasi sebesar 10,294. Sedangkan pada variabel stres kerja diketahui nilai minimum yang diperoleh sama dengan 77, nilai maksimum sama dengan 143 dengan mean yang diperoleh sama dengan 107,78 sehingga diperoleh nilai standar deviasi sebesar 17,417 .

Tabel 1. Data deskriptif penelitian

\begin{tabular}{lccccc}
\hline & $N$ & Xmin & Xmax & Mean & $\begin{array}{l}\text { Standar } \\
\text { deviasi }\end{array}$ \\
\hline $\begin{array}{l}\text { Beban } \\
\text { Kerja }\end{array}$ & 40 & 80 & 117 & 92,32 & 10,294 \\
$\begin{array}{l}\text { Stres } \\
\text { Kerja }\end{array}$ & 40 & 77 & 143 & 107,78 & 17,417 \\
\hline
\end{tabular}

Deskriptif data penelitian di atas dapat dijadikan dasar dalam pengkategorian sampel penelitian. Tujuan dari kategorisasi ini untuk menempatkan subjek ke dalam kelompok-kelompok yang berjenjang, menurut rangkaian berdasarkan atribut yang diukur (Azwar, 2017).

Berdasarkan data tabel di bawah ini, ditemukan bahwa dari 40 subjek, terdapat 4 subjek yang memiliki tingkat kategori beban kerja yang rendah dengan persentase $10 \%$, subjek dalam kategori sedang sebanyak 30 subjek dengan persentase $75 \%$, dan 6 subjek dalam kategori tinggi dengan persentase $15 \%$.

Tabel 2. Kategorisasi beban kerja

\begin{tabular}{cccc}
\hline Kategori & Skor & $\mathrm{N}$ & $\begin{array}{c}\text { Persentase } \\
(\%)\end{array}$ \\
\hline Rendah & $\mathrm{X}<(82,026)$ & 4 & $10 \%$ \\
Sedang & $(82,026) \leq \mathrm{X}<(102,614)$ & 30 & $75 \%$ \\
Tinggi & $(102,614) \leq \mathrm{X}$ & 6 & $15 \%$ \\
Jumlah & & 40 & $100 \%$ \\
\hline
\end{tabular}

Berdasarkan data tabel di bawah ini, ditemukan bahwa dari 40 subjek, terdapat 5 subjek yang memiliki tingkat kategori stres kerja yang rendah dengan persentase $12,5 \%$, subjek dalam kategori sedang sebanyak 27 subjek dengan persentase $67,5 \%$ dan 8 subjek dalam kategori tinggi dengan persentase $20 \%$.

Tabel 3. Kategorisasi stres kerja

\begin{tabular}{cccc}
\hline Kategori & Skor & N & $\begin{array}{c}\text { Persentase } \\
(\%)\end{array}$ \\
\hline Rendah & $\mathrm{X}<(90,363)$ & 5 & $12,5 \%$ \\
Sedang & $(90,363) \leq \mathrm{X}<(125,197)$ & 27 & $67,5 \%$ \\
Tinggi & $(125,197) \leq \mathrm{X}$ & 8 & $20 \%$ \\
Jumlah & & 40 & $100 \%$ \\
\hline
\end{tabular}

Tabel di bawah ini menjelaskan hubungan beban kerja dengan stres kerja. Hasilnya menunjukkan bahwa terdapat 1 perawat yang memiliki beban kerja rendah dan stres kerja yang tinggi. Dari data tersebut tidak terdapat perawat yang memiliki beban kerja tinggi namun memiliki stres kerja dalam kategori rendah.

Data lain ditemukan terdapat 5 perawat yang memiliki beban kerja tinggi dengan stres kerja yang tinggi pula. Sebanyak 24 perawat yang memiliki beban kerja sedang juga memiliki stres kerja yang sedang dan pada kategori perawat yang memiliki beban kerja dalam kategori rendah dan stres kerja rendah, terdapat 1 perawat yang mengalami kondisi tersebut.

Tabel 4. Kategorisasi tingkat beban kerja dengan stres kerja

\begin{tabular}{ccccc}
\hline Stres & \multicolumn{3}{c}{ Beban Kerja } & \multirow{2}{*}{ Total } \\
Kerja & Tinggi & Sedang & Rendah & \\
\hline Tinggi & 5 & 2 & 1 & 8 \\
Sedang & 1 & 24 & 2 & 27 \\
Rendah & 0 & 4 & 1 & 5 \\
Total & 6 & 30 & 4 & 40 \\
\hline
\end{tabular}

Uji normalitas data pada tabel di bawah ini menggunakan teknik OneSample Kolmogorov-Smirnov dengan SPSS 23.0 for windows. Hasilnya menunjukkan nilai signifikansi pada variabel beban kerja sebesar 0,058 
sedangkan pada variabel stres kerja nilai signifikansi yang diperoleh adalah 0,210. Nilai tersebut diketahui lebih besar dari $0,05$ ( $P \geq 0,05)$. Hal ini menunjukkan bahwa data dari kedua variabel berdistribusi secara normal.

Tabel 5. Uji normalitas

\begin{tabular}{lcc}
\hline \multicolumn{3}{c}{ One-Sample Kolmogorov-Smirnov Test } \\
& Signifikansi & Keterangan \\
& & \\
\hline Beban Kerja & 0,058 & $\mathrm{P} \geq 0,05$ (Normal) \\
Stres Kerja & 0,210 & $\mathrm{P} \geq 0,05$ (Normal) \\
\hline
\end{tabular}

Uji linearitas data pada tabel di bawah ini menggunakan test for linearity pada program SPSS 23.0 for windows menunjukkan nilai signifikansi deviation from linearity sebesar 0,087. Nilai ini lebih besar dari $0,05 \quad(\mathrm{P} \geq 0,05)$, menunjukkan bahwa data variabel beban kerja dan stres kerja memiliki hubungan yang linear.

Tabel 6. Uji linearitas

\begin{tabular}{lll}
\hline \multicolumn{1}{c}{ Variabel } & $\begin{array}{l}\text { Sig. deviation } \\
\text { from linearity }\end{array}$ & Keterangan \\
\hline Beban Kerja & 0,087 & Alat ukur (Linear) \\
Stres Kerja & 0,087 & Alat ukur (Linear) \\
\hline
\end{tabular}

Hasil uji korelasi data di bawah ini menunjukkan nilai signifikansi 0,004. Nilai ini lebih kecil dari 0,01 sehingga dapat dikatakan bahwa terdapat hubungan antara beban kerja dengan stres kerja. Adapun nilai koefisien korelasi sebesar 0,450 yang bertanda positif menunjukkan bahwa adanya hubungan yang positif antara kedua variabel yang berada pada kategori tinggi.

Tabel 7. Uji korelasi

\begin{tabular}{lll}
\hline \multicolumn{1}{c}{ Variabel } & Korelasi pearson & Sig. \\
\hline Beban Kerja & 0,450 & 0,004 \\
Stres Kerja & 0,450 & 0,004 \\
\hline
\end{tabular}

Penelitian ini bertujuan untuk menjawab hipotesis apakah ada hubungan antara beban kerja dengan stres kerja pada perawat Rumah Sakit Jiwa Provinsi
Sulawesi Tenggara. Kriteria sampel penelitian adalah perawat yang berusia 26-35 tahun dengan masa kerja 1-4 tahun sehingga diperoleh sampel sebanyak 40 perawat. Berdasarkan hasil uji korelasi ditemukan bahwa terdapat hubungan antara kedua variabel tersebut pada perawat Rumah Sakit Jiwa Provinsi Sulawesi Tenggara sehingga hipotesis dalam penelitian ini diterima.

Penelitian ini berbeda dengan penelitian Dewi (2018) yang dilakukan pada 40 orang kuli panggul yang terikat dalam organisasi SPTI (Serikat Pekerja Transportasi Indonesia) di Pasar Gede Surakarta. Hasil penelitiannya menunjukkan tidak ada hubungan antara beban kerja dengan stres kerja.

Kedua variabel dalam penelitian ini yaitu variabel beban kerja dan stres kerja memiliki hubungan yang signifikan. Hal ini disebabkan karena salah satu faktor penyebab stres kerja adalah beban kerja Hurrel (Munandar, 2014). Beban kerja berlebih dan beban kerja terlalu sedikit dapat menyebabkan stres kerja. Beban kerja berlebih timbul sebagai akibat dari tugas-tugas yang terlalu banyak yang diberikan kepada tenaga kerja untuk diselesaikan dalam waktu tertentu. Beban kerja terlalu sedikit yaitu jika tugas tersebut tidak menggunakan keterampilan dan potensi dari tenaga kerja.

Berdasarkan hasil penelitian yang telah dilakukan diketahui bahwa sebagian besar perawat Rumah Sakit Jiwa mengalami stres dalam pekerjaan. Hal ini disebabkan karena banyaknya tuntutan tugas. Perawat Rumah Sakit Jiwa Provinsi Sulawesi Tenggara memiliki uraian tugastugas yang terdiri dari; melakukan pengkajian keperawatan dasar, melakukan massage pada kulit tertekan serta memfasilitasi keluarga untuk mengekspresikan perasaan. Selain itu, perawat melakukan komunikasi terapeutik dalam pemberian asuhan keperawatan, melakukan restrain/fiksasi pada pasien dalam rangka melakukan upaya preventif, melakukan dokumentasi proses 
keperawatan pada tahap pengkajian keperawatan. Adapun tugas lainnya adalah melakukan dokumentasi pelaksanaan tindakan keperawatan, memfasilitasi suasana lingkungan yang tenang dan aman, memfasilitasi kebutuhan spiritual klien dan memberikan dukungan dalam kehilangan ataupun berduka serta kematian.

Banyaknya tuntutan tugas yang diberikan dan ketidaksesuaian antara jumlah pasien dan jumlah perawat yang tersedia dalam setiap shift menjadi penyebab munculnya stres pada perawat Rumah Sakit Jiwa Provinsi Sulawesi Tenggara. Hal ini didukung oleh pendapat Runtu, Pondaag \& Hamel (2018) bahwa banyaknya pekerjaan yang melebihi kapasitas menyebabkan kondisi fisik perawat akan mudah lelah dan mudah tegang.

Shift kerja yang diterapkan ialah tiga rotasi yaitu shift pagi pukul 08.0014.00 WITA dengan jumlah perawat 4-5 orang karena pasien rawat inap lebih banyak masuk saat pagi hari. Shift sore dimulai pukul 14.00-21.00 WITA dengan jumlah perawat 2-3 orang dan shift malam mulai pukul 21.00-08.00 WITA dengan jumlah perawat adalah 2-3 orang. Sementara jumlah pasien sebanyak 10-15 orang setiap ruangan. Biasanya 1 perawat Rumah Sakit Jiwa melakukan 1 sampai 2 tugas kepada 10 sampai 14 pasien karena kurangnya jumlah perawat yang tersedia dalam setiap shift. Tugas-tugas perawat harus diselesaikan dalam satu hari kerja. Hal ini sesuai dengan pendapat Febriani (2017) bahwa rasio antara jumlah perawat dan pasien dengan standar 1:10 tidak seimbang karena akan menyebabkan perawat memiliki beban kerja yang lebih banyak sehingga memicu stres kerja. Keterbatasan kapasitas perawat dibandingkan jumlah pasien menyebabkan perawat akan mengalami kelelahan dalam bekerja karena kebutuhan pasien terhadap asuhan keperawatan lebih besar dari standar kemampuan perawat.

Berdasarkan observasi yang peneliti lakukan pada tanggal 15
September 2020, aspek stres kerja dari perilaku juga ditemukan pada perawat Rumah Sakit Jiwa. Ditunjukkan dengan adanya perawat yang sering datang terlambat tidak sesuai dengan jam kerja yang ditentukan. Selain itu, wawancara juga dilakukan pada bulan September 2020 kepada 3 perawat ruang akut yang berusia 27-29 tahun. Hasilnya diketahui bahwa perawat tersebut sering merasakan gejala stres kerja seperti kebosanan kerja, sakit kepala, ketegangan otot dan kelelahan selama menangani pasien. Hal ini disebabkan karena karakteristik pasien yang berbeda dengan pasien di Rumah Sakit Umum. Karakteristik pasien yang berbeda tersebut menambah beban tersendiri bagi perawat karena sulitnya berkomunikasi dengan pasien saat melakukan tindakan keperawatan dan perilaku agresif pasien yang tidak dapat diprediksi. Biasanya penyakit yang dialami pasien memiliki diagnosa sama tetapi terkadang respon pasien berbeda sehingga membuat perawat selalu merasa waspada saat menangani pasien.

Selain itu, terdapat hubungan yang signifikan antara beban kerja dan stres kerja juga disebabkan oleh tuntutan kerja pada shift malam. Pekerja shift malam lebih sering mengeluh tentang kelelahan Hurrel (Munandar, 2014). Hal ini sesuai dengan pernyataan perawat Rumah Sakit Jiwa bahwa pada shift malam, perawat dituntut harus selalu mengawasi pasien. Pada malam hari sering terdapat pasien yang melakukan percobaan bunuh diri dan sering terjadi pertengkaran sesama pasien di dalam sel terutama pasien yang sebelumnya telah dipulangkan dan kembali lagi ke Rumah Sakit Jiwa. Pasien tersebut biasanya membawa benda-benda yang diperlukan untuk melakukan percobaan bunuh diri. Perawat harus mengurangi waktu istirahatnya untuk mengawasi pasien sehingga menyebabkan kelelahan. Apabila hal tersebut terus terjadi, maka akan menimbulkan stres bagi diri perawat sendiri.

Penelitian ini sejalan dengan hasil penelitian terdahulu yang dilakukan oleh 
Aiska (2014) pada 105 perawat Rumah Sakit Jiwa Grhasia. Setelah dilakukan analisa bivariat untuk mengetahui faktorfaktor yang berhubungan pada tingkat stres kerja perawat, diketahui bahwa beban kerja paling banyak dipilih oleh responden. Hasil penelitiannya menunjukkan beban kerja berpengaruh secara signifikan terhadap stres kerja.

Penelitian relevan juga ditemukan pada hasil penelitian Fachruddin, Santoso, dan Zakiyah (2018) yang dilakukan pada 40 perawat yang bekerja di Instalasi Rawat Intensif Rumah Sakit Umum Bangil. Hasilnya menunjukkan beban kerja berhubungan dengan stres kerja yang disebabkan karena jumlah pasien dan jumlah perawat yang tidak sesuai. Peneliti juga melakukan wawancara pada tanggal 12-13 Oktober 2020 terkait dengan beban pekerjaan kepada 2 perawat ruang Asoka dan 2 perawat ruang Srikandi yang berusia 29 sampai 31 tahun dengan masa kerja 3-4 tahun. Hasil dari wawancara tersebut menunjukkan bahwa perawat mengalami stres ketika menghadapi pasien jiwa disebabkan karena masih sedikit keterampilan dan pengalaman dalam menangani pasien tersebut. Hal ini didukung oleh pendapat Kawatu (2012) bahwa individu yang memiliki pengalaman kerja lebih lama cenderung lebih tahan terhadap tekanan-tekanan yang dialami dalam pekerjaan dibandingkan individu dengan masa kerja yang lebih singkat karena memiliki pengalaman yang sedikit. Hal ini juga didukung oleh hasil penelitian Fuada, Wahyuni dan Kurniawan (2017) yang menunjukkan bahwa perawat yang mengalami stres kerja berat paling banyak dialami oleh perawat dengan masa kerja yang singkat.

\section{Kesimpulan}

Berdasarkan data penelitian yang dilakukan terkait dengan hubungan antara beban kerja dengan stres kerja pada perawat Rumah Sakit Jiwa Provinsi Sulawesi Tenggara, hasilnya adalah terdapat hubungan antara beban kerja dengan stres kerja pada perawat Rumah Sakit Jiwa Provinsi Sulawesi Tenggara dengan nilai signifikansi yang menunjukkan ada hubungan antara beban kerja dengan stres kerja pada perawat Rumah Sakit Jiwa Provinsi Sulawesi Tenggara. Sehingga hipotesis penelitian diterima. Hasil penelitian juga menunjukkan angka koefisien korelasi yang positif artinya semakin tinggi beban kerja maka semakin tinggi stres kerja. Sebaliknya, semakin rendah beban kerja maka semakin rendah juga stres kerja.

Perawat Rumah Sakit Jiwa diharapkan lebih memanfaatkan waktu secara efektif dalam menyelesaikan tugastugas yang dibebankan agar tugas tersebut tidak menumpuk sehingga dapat diselesaikan tepat waktu dan dapat terhindar dari stres kerja serta tetap menilai positif setiap beban kerja dan mencari solusi terbaik sehingga pekerjaan dapat dijalankan dengan baik. Peneliti selanjutnya diharapkan untuk melakukan penelitian lebih lanjut terkait faktor-faktor lain yang dapat mempengaruhi stres kerja pada perawat seperti kerja shift, peran individu dalam organisasi, hubungan dalam pekerjaan, dan lain sebagainya dengan sampel penelitian yang lebih banyak.

\section{Daftar Pustaka}

Aiska, S. (2014). Analisis Faktor-faktor yang Berpengaruh pada Tingkat Stres Kerja Perawat di Rumah Sakit Jiwa Grhasia Yogyakarta. Skripsi. Yogyakarta: Universitas Muhammadiyah Yogyakarta

Almasitoh, U., H. (2011). Stres Kerja Ditinjau dari Konflik Peran Ganda dan Dukungan Sosial pada Perawat. Jurnal Psikologi Islam, 8(1), 63-82.

Anoraga, P. (2014). Psikologi Kerja. Jakarta: Rineka Cipta 
Azwar. (2017). Metode Penelitian Psikologi. Yogyakarta: Pustaka Pelajar

Budi, S., C. (2011). Manajemen Unit Kerja Rekam Medis. Yogyakarta: Quantum Sinergis Media

Dewi, A., I., P. (2018). Hubungan antara Beban Kerja dengan Stres Kerja pada Kuli Panggul di Pasar Gede Surakarta. Skripsi. Surakarta: Universitas Muhammadiyah Surakarta

Dhania, D. R. (2010). Pengaruh Stres Kerja, Beban Kerja Terhadap Kepuasan Kerja. Jurnal Psikologi Universitas Muria Kudus, I(1), 15-23.

Eliyana. (2016). Faktor-faktor yang Berhubungan dengan Burnout Perawat Pelaksana di Ruang Rawat Inap RSJ Provinsi Kalimantan Barat Tahun 2015. Jurnal Administrasi Rumah Sakit, 2(3), 172-182.

Fachruddin, N., Santoso, W., \& Zakiyah, A. (2018). Relationship Between Workload with Work Stress on Nurses in Intensive Installation of Bangil General Hospital. International Journal of Nursing and Midwifery Science, 2, 311-321.

Fahmi, S. (2016). Pengaruh Stres Kerja dan Konflik Kerja terhadap Semangat Kerja Karyawan pada PT. Omega Mas Pasuruan. Jurnal Ekonomi Modernisasi, 12(3), 107-116.

Febriani, S. (2017). Gambaran Stres Kerja pada Perawat di Ruang Rawat Inap Bagian Perawatan Jiwa Rumah Sakit Khusus Daerah Provinsi Sulawesi Selatan. Skripsi. Makassar: UIN Alauddin Makassar

Fuada, N., Wahyuni, I., \& Kurniawan, B. (2017). Faktor-faktor yang Berhubungan dengan Stres Kerja pada
Perawat Kamar Bedah di Instalasi Bedah Sentral RSUD K.R.M.T Wongsonegoro Semarang. Jurnal Kesehatan Masyarakat, 5(5), 255263.

Haryanti., Aini, F., \& Purwaningsih, P. (2013). Hubungan antara Beban Kerja dengan Stres Kerja Perawat di Instalasi Gawat Darurat RSUD Kabupaten Semarang. Jurnal Managemen Keperawatan, 1(1), 4856.

Isnainy, U, C, A, S., Furqoni, P, D., Aryanti, L., \& Asdi, L, S. (2019). Hubungan Beban Kerja, Budaya Kerja dan Lama Kerja terhadap Stres Kerja Perawat di Ruang Irna III Rumah Sakit Umum Daerah DR. H Abdul Moeloek Provinsi Lampung. Malahayati Nursing Journal, 1(1), 111.

Kalendesang, P., Hendro, B \& Reginus T. M. (2017). Hubungan Konflik Peran Ganda Perawat Wanita sebagai Care Giver dengan Stres Kerja di Ruangan Rawat Inap Rumah Sakit Jiwa Prof. Dr. V. Ratumbuysang Provinsi Sulawesi Utara. Jurnal Keperawatan, 5(1).

Kawatu, P. (2012). Bahan Ajar Kesehatan dan Keselamatan Kerja. FKM Unsrat. Manado

Kirana, V, D, C., \& Dwiyanti, E. (2017). Hubungan Stres Kerja dengan Kelelahan pada Perawat dengan Metode Pengukuran Dass 21 dan Ifrc. Jurnal Ilmiah Kesehatan Mediahusada, 6(1), 133-140.

Maharani, R., \& Budianto, A. (2019). Pengaruh Beban Kerja terhadap Stres Kerja dan Kinerja Perawat Rawat Inap Dalam. Journal of Management Review, 3(2), 327-332. 
Muatsiroh, A \& Siswati. (2017). Hubungan antara Kecerdasan Interpersonal dengan Stres Kerja pada Perawat Instalasi Rawat Inap di Rumah Sakit Jiwa Daerah Surakarta. Jurnal Empati, 6(1), 34-39.

Munandar, A. S. (2014). Psikologi Industri dan Organisasi. Jakarta: UIPress.

Permatasari, Y, D, A., \& Utami, M, S. (2018). Koping Stres dan Stres pada Perawat di Rumah Sakit Jiwa X. Jurnal Pemikiran dan Penelitian Psikologi, 23(2), 121-136.

Pongantung, M., Kapantouw, N, H., \& Kawatu, P, A, T. (2018). Hubungan antara Beban Kerja dan Stres Kerja dengan Kelelahan Kerja pada Perawat Rumah Sakit GMIM Kalooran Amurang. Jurnal Kesmas, 7(5), 1-7.

Purbaningrat, P. M. (2015). Pengaruh beban kerja terhadap kepuasan kerja dengan stres kerja sebagai variabel mediasi. Jurnal managemen unud, 4(5), 1149-1165.

Puteri, L., A., \& Syaebani, M., I. (2018). Employees Work Stress Level in the Hospital. International Research Journal of Business Studies, 11(3), 231-243.

Robbins, S. P., \& Judge. T. A. (2016). Perilaku Organisasi. Jakarta: Salemba Empat

Runtu, V, V., Pondaag, L., \& Hamel, R. (2018). Hubungan Beban Kerja Fisik dengan Stres Kerja Perawat di Ruang Instalasi Rawat Inap Rumah Sakit Umum GMIM Pancaran Kasih Manado. Jurnal Keperawatan 6(1), 17.
Setiyana, V.,Y. (2013). Forgiveness dan Stres Kerja Terhadap Perawat. Jurnal Ilmiah Psikologi Terapan, 1(2), 376396. 